\title{
Research on English Informationized Teaching in Application-oriented Undergraduate Colleges
}

\author{
Weiwei Zou \\ Nanchang Institute of Science and Technology, Nanchang, China
}

Keywords: application-oriented undergraduate college; English informationized teaching; research

\begin{abstract}
With the development of China's economy and the increasing opening-up degree, the communication between China and other countries in the world is more frequent. English, as the common language in the whole world, plays a prominent role in communication. Therefore, colleges and universities at all levels gradually improve their importance on English teaching. At present, application-oriented undergraduate colleges generally set English as compulsory curriculum to enhance students' ability of adapting to the future society through English teaching. However, there are still some problems in English teaching, which fails to keep up with the social development trend. In order to solve these problems, colleges and universities shall actively introduce informationized teaching mode and adopt modern teaching methods, so that students can be equipped with stronger English ability
\end{abstract}

Nowadays, the competition in all walks of life is gradually fiercer, which, in essence, is the competition of talents. Talents with stronger English communication ability is the key talent required by the society. Therefore, colleges and universities all pay attention to English teaching and the cultivation of related talents. Students in application-oriented colleges have relatively weak English basis, lacking of English learning interest and motivation, which cannot be effectively improved in traditional teaching mode. In order to solve the problems in current English teaching, teachers shall actively adapt to the changes of social trend, innovate teaching mode, apply informationized teaching system in classroom, promote students' learning interest, and improve the quality of English teaching.

\section{The Current Status of English Teaching in Application-oriented Undergraduate Colleges}

Different from general undergraduates, application-oriented undergraduate colleges have their own characteristics in talent cultivation mode, cultivation objective, and cultivation method, belonging to brand new education system. The training focus of applied undergraduate talents is the practical ability and the mastering of theoretical knowledge. In order to ensure that students are equipped with sufficient theoretical knowledge, the training of students' innovative ability and abstract ability shall be strengthened, to continuously enhance their practical ability with professional knowledge. [1] English is the compulsory curriculum in application-oriented undergraduate colleges. And there are still many problems in implementing English teaching in these colleges. Many teachers still adopt traditional teaching mode, where teacher is the core, and students passively accept the cramming of knowledge. Teachers pay more attention to the explanation of grammar knowledge, and divide articles into different knowledge points. Students have insufficient learning interest and the classroom teaching is boring, many students have learning-weariness, which results in the fact that English proficiency cannot be effectively improved. At the same time, most application-oriented undergraduate colleges are composed of academy and vocational colleges, the quality of source of students is lower than research-oriented and academic colleges and universities, students' self-recognition and self-discipline ability is seriously not strong, and many students lack confidence in learning, with self-inferiority at different levels. [2] 


\section{The Important Role of Informationized Teaching in English Teaching of Application-oriented Undergraduate Colleges}

Modern information technology is a technology mode based on Internet and multi-media computer technology, widely applied in various industries. The information times brings greater impact on education, with informationized elements appearing in various teaching modes and teaching systems. The informationized teaching plays a promoting role for teachers and students, worthy of in-depth popularization.

The application of information technology in English teaching of application-oriented undergraduate colleges can enrich the types and contents of teaching resources. Students can absorb knowledge by visual sense and auditory sense. Teachers provide visual and auditory resources, such as multi-media courseware, teaching radio, texts and so on, based on traditional teaching contents, to satisfy different students' learning needs. The application of informationized teaching can widen the range of classroom teaching and realize the teaching system with the combination of online and offline teaching. The application of information technology under the Internet mode can break the constraints of time and space in English teaching, so that students can learn English knowledge anywhere at any time through network user terminal and intelligent devices, and teachers can realize the expansion of classroom teaching contents with this mode. At the same time, in the informationized teaching mode, students can obtain real experience of English and grasp the basic methods of communication in English in social environment. This mode also can increase the communication between teachers and students, students can freely express their viewpoints and actively share their learning experience. In this way, the common improvement of all students is significant. [3]

\section{Basic Thoughts of Informationized Teaching Reform in Application-oriented Undergraduate Colleges}

In teaching, application-oriented undergraduate colleges shall focus on students as the core of teaching activities to help student employment. The informstionized reform of English teaching shall help students grasp basic knowledge, appropriately add English teaching contents targeting the industry, enhance their language basic ability and increase English cultural teaching.

\subsection{To increase language skill teaching}

To train students' English ability, first of all, it is necessary to train students' English basic knowledge and improve their mastering level, so that they can flexibly apply these knowledge into practice. In the process of teaching, teachers should actively apply information technology to improve students' interest in learning, strengthen teaching from English pronunciation, meaning and form, improve teaching efficiency and improve students' English ability. Meanwhile, language skill teaching shall be increased to improve students' emphasis on language skills. In traditional teaching system, English teaching mainly is basic teaching, with less English listening and writing, which hinders the development and progress of students to a certain extent. Therefore, teachers are required to actively transform teaching mode, improve students' English listening and speaking ability, provide insufficient English practice opportunities for students, and enrich teaching contents with information internet technology, so that students can obtain rich learning experience and enhance their application ability. In actual teaching, combined with characteristics of students, teachers can organize English speech contest and debate competition, establish translation and writing lessons, continuously widen their thinking, and train their logical analysis ability and observation ability. [4]

\subsection{To add industry English and cultural lessons}

In the process of developing English teaching, application-oriented undergraduate colleges need to combine the actual situation of students and social needs, and increase the teaching content of industry English, including accounting English, electrical English, art English, news English, etc., 
to clarify the basic direction of talent training, being student-centered, and help students complete the transition from learning to practical application. At the same time, in order to increase students' interest in learning, teachers can make us of the informationized mode of Internet and add cultural teaching content, so as to encourage students can fully understand cultural background of English countries and deepen their understanding and recognition of English knowledge. [5]

\section{Strategies to Establish Informationized Teaching System in Application-oriented Undergraduate Colleges}

The English teaching in application-oriented undergraduate colleges shall be based on English knowledge, help students deepen their understanding and realize flexible application. The informationized teaching puts forward higher requirement for teachers. Therefore, it is necessary to conduct in-depth research, establish reasonable teaching system and guarantee teaching quality.

\subsection{The informationized mode of English information acquisition}

The information Internet technology can realize the sharing of information resources. The main behavior of college students on Internet is to acquire information resources they need, including ubiquitous resources and organized resources. The former refers to those resources can be searched in the whole range of network by search engine, and the latter means those resources presented by a certain rules, including text resources such as Wanfang and Weipu, NetEase Open Course, resource sharing course, college MOOC and other video resource contents, from which students can obtain learning materials.

\subsection{The informationized mode of English information management and record}

After acquisition, students need to manage and record information resources obtaining from Internet according to categories, for rapid search in the future. Besides, the recording of English knowledge shall also be strengthened to comb learning contents. In the informationized mode, teachers can build up online learning platform for students, ensure the flexible operation system and clear interface contents, also can adopt cloud mode to enrich students' experience, so that students can collect, arrange and analyze information effectively and improve learning effects. [6]

\section{The Informationized Teaching in Application-oriented Undergraduate Colleges - Micro-course and Flipped Classroom}

\subsection{Micro-course and flipped classroom}

The micro-course is also called the micro-video course teaching content. Teachers make the slides based on specific teaching content, with specific knowledge points as the center, and add the micro-video teaching content in the production process. The main features of this teaching mode are strong pertinence, strong interactivity, precise content, and convenient use, which is an important breakthrough point for informationized teaching, so teachers should pay more attention. Flipped classroom considers students as the core of classroom teaching, referring to the mode of self-learning based on courseware produced by teachers. In the process of classroom teaching, the interaction between teachers and students is emphasized, and students' academic performance is improved through various forms of interaction. At the same time, students can use computer, mobile phone and other functional equipment to acquire knowledge after class, and realize the extension of classroom teaching content. [7]

\subsection{The design of teaching procedures}

In order to test the effect of flipped classroom and micro-course, and to ensure the scientific and rigorous overall results, relevant teachers selected two identical classes in the school, and named experimental class and control class. The number of students in the two classes, the majors, teachers and teaching contents are exactly the same. The control class adopts the traditional teacher-centered cramming teaching mode, that is, the teacher explains the knowledge, and students listen and 
remember, and complete the homework. The experimental class adopts a combination of micro-course and flipped classroom. The content of the micro-course includes listening and video materials. The main contents include the application of key words and phrases, the extension of words, the language of words, etc. Teachers also add reasonable film and television clips to the video content, and enhance students' interest in learning. Students use the micro-course platform to preview the class first. In the classroom, flipped classroom teaching mode is adopted. Teachers organize students to conduct group discussions, evaluate and summarize, and finally complete the classroom teaching. The teaching of two classes is 6 weeks. After completing the teaching, the same content is tested and students' academic performance is compared.

\subsection{The analysis of research results}

Through the questionnaire survey, the micro-class and the effect of flipped classroom teaching are investigated. The main content of the survey is the overall acceptance and psychological changes of students after adopting a new teaching mode. Teachers distributed a total of 40 questionnaires, all of which were collected. The results showed that in experimental class, after the new teaching mode was adopted, the English learning interest increase rate is $95.0 \%$. Many students were able to actively participate in various English practice processes, 92.5\% of students believe that the informationized teaching model can improve the autonomy of learning and ensure the quality of learning. At the same time, $97.5 \%$ of students think that the new teaching mode can solve the problems encountered in the study in time. The statistics show that the survey indicators of the experimental class are clearly higher than the control class.

Table 1 The comparison of survey results in experimental class and control class

\begin{tabular}{cccc}
\hline Class $(\mathrm{n}=40)$ & $\begin{array}{c}\text { The increase rate } \\
\text { of learning interest }\end{array}$ & $\begin{array}{c}\text { The increase rate } \\
\text { of self-learning } \\
\text { ability }\end{array}$ & $\begin{array}{c}\text { The improvement } \\
\text { of } \\
\text { problem-solving } \\
\text { efficiency }\end{array}$ \\
\hline $\begin{array}{c}\text { Experimental class } \\
\text { Control class }\end{array}$ & $38(95.0)$ & $37(92.5)$ & $39(97.5)$ \\
\hline
\end{tabular}

In the teaching content testing, teachers provided the same teaching content for the experimental class and the control class. The test questions included cloze, reading comprehension, translation, choices, etc., with a full score of 100 points. The test results showed that the highest score of the experimental class was 96 points, the highest score of the control class was 87 points, the average score of the experimental class was 87.9 points, and the average score of the control class was 79.2 points. The difference in translation and cloze in two classes is not obvious, however, there is a big difference in reading comprehension.

Table 2 The comparison of learning performance in experimental class and control class

\begin{tabular}{ccc}
\hline Class $(\mathrm{n}=40)$ & The highest score & The average score \\
\hline Experimental class & 96 & 87.9 \\
Control class & 87 & 79.2 \\
\hline
\end{tabular}

Through research, it can be found that the application of micro-course and flipped classroom can significantly improve students' interest in learning, cultivate students' ability of independent learning, help students improve learning efficiency, and solve problems in the shortest time, and have an obvious effect on improving the academic performance and English use ability, worthy of further promotion. 


\section{The Informationized Teaching in Application-oriented Undergraduate Colleges -The Teaching based on Multi-media Network}

\subsection{The main advantages of English teaching with multi-media network}

The multi-media network teaching mode can enhance students' active learning awareness, and enable students to participate in the learning process independently, and the teaching environment is more open. This teaching model breaks the limitations of time and space, enabling students to complete English knowledge at any time and place. The multi-media network teaching mode can provide students with personalized learning content, and students can choose English knowledge suitable for themselves to learn. At the same time, multi-media devices are vivid, students can feel the cultural characteristics of English-speaking countries in an all-round way, enrich the learning experience, enhance learning interest and enhance autonomy. [8]

\subsection{The application strategy of multi-media network teaching}

There is a big difference between the multi-media network teaching mode and traditional teaching mode. Therefore, teachers should strengthen learning, master the application methods and techniques of multi-media devices, and collect teaching-related content on the Internet platform to create courseware suitable for students to learn, so that multimedia devices can exert its functions. Under the new teaching mode, teachers should build a new teacher-student relationship in the classroom, reasonably arrange the time of classroom teaching, avoid that the high frequency of using multimedia affects students' mastery of basic knowledge, and improve students' self-learning ability.

\section{Conclusion}

The implementation of English teaching in application-oriented undergraduate colleges requires to strengthen the application of information technology, continuously enrich teaching content, enhance students' interest in learning, help students solidly grasp basic knowledge, and improve English application ability to become high-quality talents suitable for social requirements after college study.

\section{Acknowledgements}

Fund Project: This work is the school-level humanities and social sciences project of Nanchang Institute of Science and Technology. Project Name: Research on College Teacher Identity under the Background of Staffing of Government Affiliated Institutions Reform. Project No. NGRW-17-03.

\section{References}

[1] Sun Qianqian. The Application of Information Technology in High School English Classroom Teaching -Taking Module 1, How Good Are Your Social Skills, Student Book 6, FLTRP High School English as an Example [J]. English Journal for Middle School Students, 2018(38):95.

[2] Peng Jiqun, Chen Li. Dai Wenchun. Design and Research of Higher Vocational and Professional College English Teaching in Information-based Teaching Environment [J]. Health Vocational Education, 2018,36(19):16-17.

[3] Qin Dongmei. Research on the Cultivation Path of College Students' English Self-learning Ability in Information-based Teaching [J/OL]. Journal of Ningbo Institute of Education, 2018(05):91-94.

[4] Liu Xiaoyan. Exploration of English Teaching Design of Higher Vocational College in Information-based Environment -Taking Body Language in Communication as an Example [J/OL]. Light Industry Science and Technology, 2018(10):177-178+181.

[5] Wang Jing, Wang Yiyi, Li Lan, Teng Fei. Research and Practice of Higher Vocational English 
Public Teaching Based on Flipped Classroom [J]. The Science Education Article Collects (Mid-month Issue), 2018(09):164-165.

[6] Luo Na, Zhao Hua, Song Lina. Research on the Mode of Cultivating English Normal Students' Lesson Interpretation Ability with Micro-teaching in Information-based Background [J]. College Entrance Examination, 2018(26):6.

[7] Zhu Yi. Research on English Teaching Strategy to Cultivate Higher College Students' Occupational Core Ability with the Carrier of Associations -Taking Wuxi Higher Health Vocational Technology School as an Example [J]. Vocational Technology, 2018,17(09):89-91.

[8] Kuang Shanyun, Huang Runmei, Lu Yun, He Shuang. The Analysis of Current Status and Suggestions on Promotion of Information-based Teaching Practice of Basic Education -Based on the Survey of Video Class Case of "Ministerial-level UOOC” [J]. China Educational Technology, 2018(09):61-68. 